\title{
Discrimination of four Japanese Tetranychus species (Acari: Tetranychidae) using PCR-RFLP of the inter-transcribed spacer region of nuclear ribosomal DNA
}

\author{
Mh. Osakabe, ${ }^{*, 3}$ Takuya Hirose ${ }^{1,4}$ and Masaru Satō ${ }^{2,5}$ \\ Department of Plant Protection, National Agriculture Research Center, Tsukuba, Ibaraki 305-8666, Japan \\ ${ }^{1}$ Kochi Prefectural Agricultural Research Center, Nankoku, Kochi 783-0023, Japan \\ ${ }^{2}$ Yokohama Plant Protection Station, Yokohama, Kanagawa 231-0801, Japan
}

(Received 26 December 2001; Accepted 3 April 2002)

\begin{abstract}
To establish diagnostic DNA markers useful for discriminating economically important Tetranychus species, especially T. kanzawai, from other species of the urticae complex, we sequenced the ribosomal ITS region, including ITS1, 5.8S, and ITS2, of four Tetranychus species and analyzed recognition sites of restriction endonucleases. We established genetic criteria for discriminating T. kanzawai, T. urticae, T. pueraricola and T. ludeni using PCR-RFLP. We propose the establishment of a worldwide PCR-RFLP catalogue.
\end{abstract}

Key words: Tetranychus, ITS, PCR-RFLP, ribosomal DNA, species discrimination

\section{INTRODUCTION}

The genus Tetranychus (spider mites) includes serious common pests of legumes, vegetables, ornamentals, and fruit trees. Because its distribution is limited to East Asia and Australia (Ehara, 1999) and because of its development of resistance to many acaricides, Tetranychus kanzawai Kishida is a target pest for quarantine in international trade. Because female spider mites disperse much more than immature stages and adult males, a method for discriminating adult Tetranychus females is needed for quarantine, population dynamics studies, and crop damage forecastings. According to Ehara (1999), ten Tetranychus species live in Japan. However, only two species, Tetranychus ludeni Zacher and Tetranychus okinawanus Ehara can be identified morphologically in adult females. The remaining eight species, which are grouped into the $u r$ ticae complex, are identified by the shape of the aedeagus (Ehara, 1999). No key for identifying adult females of the urticae complex has been provided, except for some tentative characterization methods (Enohara and Amano, 1996).
Goka and Takafuji (1997) revealed enzymatic differences among adult females of seven Tetranychus species and suggested a genetic marker, combining phosphoglucoisomerase (PGI) and malate dehydrogenase (MDH) since not only interspecific but also intraspecific variation was found in PGI and $\mathrm{MDH}$ and some alleles were common among distinct species. Further, the position of detected bands is usually evaluated relative to the distance from the origin in comparison with standard samples. Therefore, the process of data analysis for identification would be complicated. Enohara and Amano (1996) showed differences in esterase isozymes among Tetranychus species. However, the activities of esterase isozymes change with host plant species (Mullin and Croft, 1983; Osakabe, 1984, 1987), and the isozymes are sometimes quite polymorphic within a species (Šula and Weyda, 1983).

Nuclear ribosomal DNA (rDNA) usually expresses low variation within a species, whereas nucleic acid substitutions are easily found among related species, especially in the rDNA's internal transcribed spacer (ITS) region. The analysis of re-

\footnotetext{
* To whom correspondence should be addressed at: E-mail: mhosaka@kais.kyoto-u.ac.jp

${ }^{3}$ Present address: Laboratory of Ecological Information, Graduate School of Agriculture, Kyoto University, Kyoto 606-8502, Japan

${ }^{4}$ Present address: Department of Agriculture, Forestry and Fisheries, Kochi Prefectural Government, Kochi, Kochi 780-0850, Japan

${ }^{5}$ Present address: Department of Plant Protection, National Agricultural Research Center for Kyushu Okinawa Region, NARO, Nishigoshi, Kumamoto 861-1192, Japan
} 
striction fragment-length polymorphism following PCR (PCR-RFLP) is a relatively inexpensive and simple method of detecting DNA polymorphisms, and is useful in species diagnostics (Gasparich et al., 1995; Navajas and Fenton, 2000). In fact, the use of PCR-RFLP in the ITS region has already been used for species diagnostics in nematodes (Nasmith et al., 1996; Orui, 1996; Orui and Mizukubo, 1999). In spider mites, Gotoh et al. (1998) showed diagnostic RFLP in part of the ITS region, ITS2, between Tetranychus urticae Koch and Tetranychus pueraricola Ehara et Gotoh. The usefulness of ITS2 in solving Tetranychus species affiliations was proved by Navajas et al. (1997), and that of another ribosomal ITS region, ITS1, was suggested by Hinomoto and Takafuji (2001).

T. kanzawai, T. urticae, T. pueraricola and $T$. ludeni may all occur on the same plant together, and are sometimes misidentified. T. urticae, which includes two forms (green form and red form), is cosmopolitan, and has developed widespread acaricide resistance. T. pueraricola was recently recorded in Japan by Ehara and Gotoh (1996). The domestic and international distributions of this mite have not been sufficiently investigated. $T$. $l u$ deni is widespread on a wide range of agricultural crops and wild plants around the world (Ehara and Masaki, 1989). This species can possibly be discriminated from the urticae complex by the relative position of a set of duplex setae to tactile setae on tibia I of females (Ehara, 1999). However, Tetranychus desertorum Banks distributed outside of Japan, resembles T. ludeni in these morphological characteristics (Ehara and Masaki, 1989).

In this study, we aimed at establishing diagnostic DNA markers useful for discriminating the four species, T. kanzawai, T. urticae, T. pueraricola and T. ludeni. We sequenced and analyzed on the ribosomal ITS region of these species. We found a useful set of restriction enzymes for use in diagnostic PCR-RFLP and propose the establishment of a worldwide catalogue of DNA markers.

\section{MATERIALS AND METHODS}

Collection records and identification of mites. Local populations of Tetranychus species were collected from central and western Japan in 1997 and 1998, and four laboratory strains were provided by Ibaraki University and the National Institute of
Agrobiological Science (Table 1). Twenty-four adult females of each population, except the laboratory strains, were individually reared on small detached kidney bean leaves $(2 \times 2 \mathrm{~cm})$ set on wet cotton, and kept at $22^{\circ} \mathrm{C}$ under $16 \mathrm{~L}-8 \mathrm{D}$ until eggs deposited by the females developed to adults. After adult emergence of the next generation, three adult male progeny were selected from each detached leaf and individually mounted on slides in Hoyer's medium. They were identified from the key described by Ehara (1996). Progeny from nine to 15 original females in each population were successfully identified and kept as sub-populations. Lines identified as the same species in each population were mixed and increased for DNA analysis.

Tetranychus parakanzawai Ehara, which is closely related to T. kanzawai was newly described after our identification was done (Ehara, 1999). However, morphological differences between the two species are very small. It was known that unidirectional fertilization could occur between $T$. parakanzawai and T. kanzawai (Gomi and Gotoh, 1996). Therefore, the populations originally identified as T. kanzawai on the basis of morphology had to be reidentified as T. kanzawai or T. parakanzawai. Therefore, the populations originally identified as T. kanzawai were reciprocally crossed with reliable laboratory strains of $T$. parakanzawai $(\mathrm{Tp}=\mathrm{I} 2)$ and T. kanzawai (Tk), supplied by Ibaraki University. The Tk strain was collected from Camellia sinensis (L.) O. Kuntze in Kanaya, Shizuoka Prefecture, Japan, in May 1993, and the Tp from Pueraria lobata (Willd.) in Ami, Ibaraki Prefecture, Japan, in Oct. 1993 (Gomi and Gotoh, 1996).

Quiescent deutonymphs of populations originally identified as T. kanzawai (tester) and the standard strains $\mathrm{Tp}$ and $\mathrm{Tk}$ were separately placed on detached kidney bean leaves of $5 \times 5 \mathrm{~cm}$ on pieces of wet cotton. Three new adult females of one tester that emerged were then transferred to a smaller detached kidney bean leaf $(2 \times 2 \mathrm{~cm})$, and three adult males of one standard strain were introduced to the leaf from the stock culture. After a couple of days at $25^{\circ} \mathrm{C}, 16 \mathrm{~L}-8 \mathrm{D}$, the adults were removed from the leaf. The eggs deposited on the leaf were maintained, and the sex ratio of the offspring was checked two weeks later. Crosses between standard strain females $\times$ tester males and a control reciprocal cross between the standard 


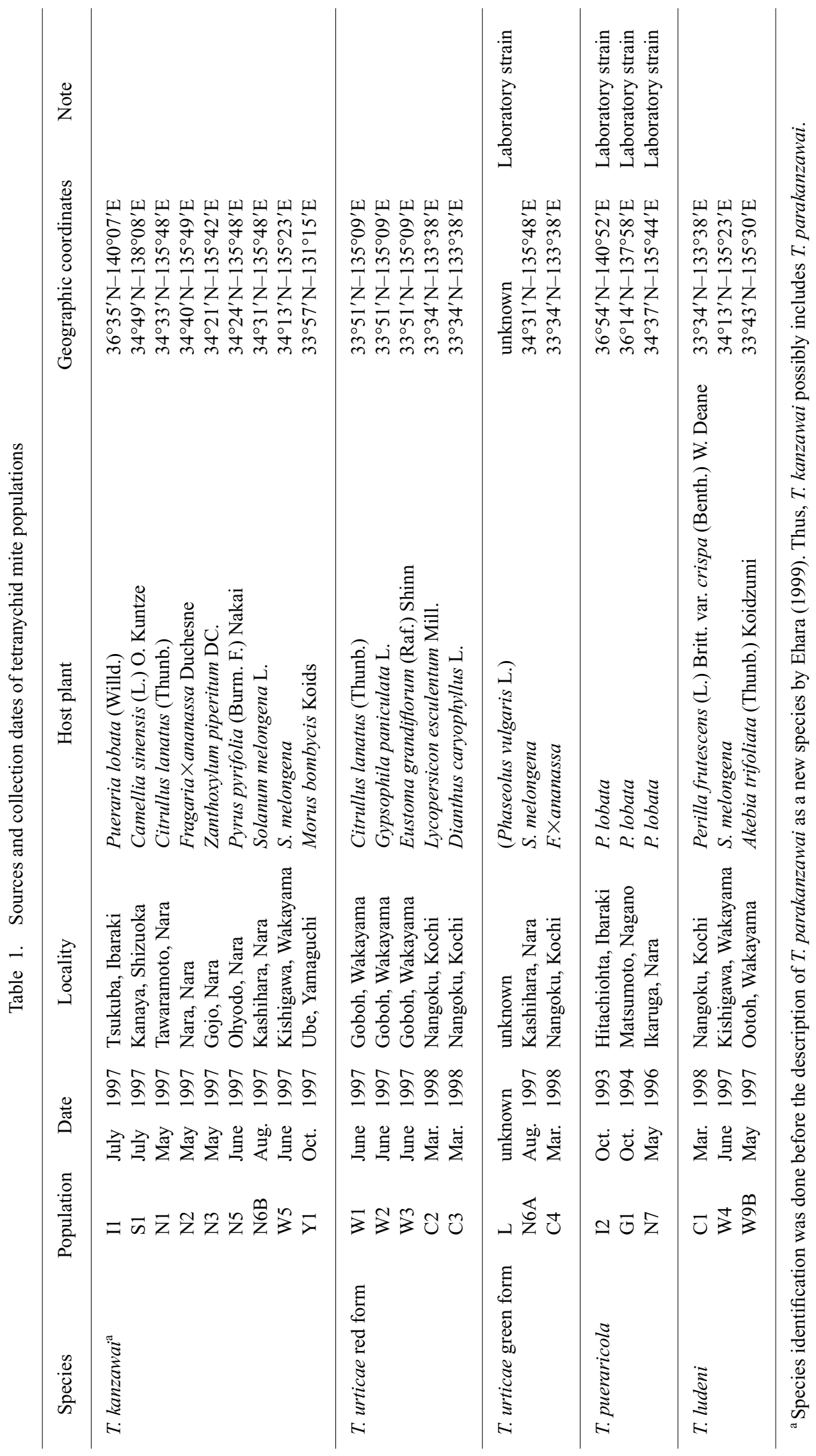


strains were done in the same manner. Tetranychus species show arrhenotoky (Helle and Pijnacker, 1985). Because T. parakanzawai females crossed with $T$. kanzawai males produce no female offspring, whereas some female offspring were produced from crosses between T. kanzawai females and $T$. parakanzawai males, the mites were decisively identified from the sex ratios in the offspring produced by the reciprocal crosses.

Sample preparation for DNA analysis. We used the DNA preparation method of Goka et al. (2001) with modifications. A single adult female was homogenized in $20 \mu \mathrm{l}$ of lysis buffer $(10 \mathrm{mM}$ Tris-HCl [pH 8.0], $100 \mathrm{~mm}$ EDTA, 0.5\% Igepal CA-630 [Sigma], $10 \mathrm{~mm} \mathrm{NaCl}, 1 \mathrm{mg} / \mathrm{ml}$ Protenase $\mathrm{K})$ using a glass rod in a sample tube. The homogenate was incubated at $65^{\circ} \mathrm{C}$ for $15 \mathrm{~min}$ and then at $95^{\circ} \mathrm{C}$ for $10 \mathrm{~min}$. After incubation, the homogenate was diluted with $380 \mu 10.1 \times \mathrm{TE}$ buffer (1 mM Tris- $\mathrm{HCl}$ [pH 8.0], 0.1 mM EDTA) and stored at $-20^{\circ} \mathrm{C}$ until use in a polymerase chain reaction (PCR) as a DNA template.

PCR amplification. The primers used to amplify the ITS region were rD02 forward: $5^{\prime}$-GTCGTAACAAGGTTTCCGTAGG-3' (Hinomoto and Takafuji, 2001), and HC2 reverse: 5'-ATATGCTTAAGTTCAGCGGG-3' (Navajas et al., 1994). PCR assays were conducted with $1 \mu \mathrm{l}$ of each DNA template in a total reaction volume of $20 \mu \mathrm{l}$ buffer (2.5 $\mathrm{mM} \mathrm{MgCl}_{2}, 50 \mathrm{~mm} \mathrm{KCl}, 10 \mathrm{~mm}$ Tris-HCl [pH 8.3]) containing $0.2 \mathrm{~mm}$ of each dNTP, 10 pmoles of each primer, and 0.5 units of AmpliTaq DNA polymerase (PE Applied Biosystems). PCR conditions were an initial $1 \mathrm{~min}$ at $95^{\circ} \mathrm{C}$; followed by $30 \mathrm{~s}$ at $92^{\circ} \mathrm{C}, 30 \mathrm{~s}$ at $50^{\circ} \mathrm{C}$, and $1 \mathrm{~min}$ at $72^{\circ} \mathrm{C}$ for 30 cycles; and a final $10 \mathrm{~min}$ at $72^{\circ} \mathrm{C}$ (GeneAmp PCR System 2400; PE Applied Biosystems). The resulting PCR products (ca. 1,200 bp) were checked by agarose gel $(2 \%)$ electrophoresis using the TAE buffer system and visualization by ethidium bromide staining under UV light, and then used for sequencing or RFLP analysis.

Sequencing and analysis of recognition sites for restriction enzymes. Amplified ITS fragments of T. kanzawai (S1), T. urticae (W1), T. pueraricola (I2) and T. ludeni (W4) were cloned into pCRII plasmids by using a TA Cloning Kit (Invitrogen) and transformed into competent Escherichia coli cells (INV $\alpha \mathrm{F}^{\prime}$ ). The transformant was selected on LB plates containing kanamycin and X-gal and cultivated in $4 \mathrm{ml}$ of LB medium overnight. Plasmids were then extracted and dissolved in TE buffer (200 ng/ $\mu$ l final concentration). Sequencing was performed in an ABI Model 373S Sequencer (Applied Biosystems) using an ABI Prism Dye Terminator Kit with M13-40 forward and M13 reverse primers; specific primers for ITS: $\mathrm{rD} 02$ and HC2; and five inner-primers: rD03 reverse: $5^{\prime}$-TGGCTGCGTTCTTCATCG-3' (Hinomoto and Takafuji, 2001), LC1 forward: 5'-CGAGTATCGATGAAGAACGCA-3' (Navajas et al., 1994), ITS1378 forward: 5'-GCTTATGCTGACGGC-3', ITS1512 forward: 5'-TAAAAGTCCCACGGT-3' and ITS2-83 reverse: 5'-TGACCTCGGAAAAGACCC-3'. The last three primers were based on the sequence of $T$. urticae used in this study. Recognition sites for restriction endonucleases on obtained sequences were analyzed with Genetyx-Win software (Software Development). Two colonies of transformed $E$. coli were used for the sequence analysis in each species.

PCR-RFLP detection. The ITS fragments of all populations amplified as above were digested by two restriction endonucleases, DraI and $A f a \mathrm{I}$, whose recognition sites varied among species in the above sequence analysis. For the digestion, 8.5 or $9 \mu \mathrm{l}$ of amplified reactions was used directly. The resulting digested fragments were separated by $3.5 \%$ agarose gel electrophoresis (Agarose X, Nippon Gene) and visualized by ethidium bromide staining under UV light to compare the restriction patterns.

\section{RESULTS}

Sex ratio of offspring after crossing between local populations and standard strains of $T$. kanzawai and T. parakanzawai

The sex ratio (female/total) of offspring produced after the reciprocal cross between the standard T. kanzawai strain (Tk) and the standard $T$. parakanzawai strain (Tp) was low or 0 (Table 2). After the cross between Tk females and Tp males, a small number of $F_{1}$ adult females emerged, although the sex ratio was biased to male. No female offspring appeared after the cross between the Tp females and the Tk males.

In most of the reciprocal crosses between local populations and $\mathrm{Tk}$, the sex ratios of the offspring were equal or female-biased (Table 2). However, no 
Table 2. Sex ratios in offspring after copulation between local populations and standard strains of T. kanzawai and T. parakanzawai

\begin{tabular}{|c|c|c|c|c|c|c|c|}
\hline \multicolumn{4}{|c|}{ Copulation with $T$. kanzawai (Tk) } & \multicolumn{4}{|c|}{ Copulation with T. parakanzawai (Tp) } \\
\hline $9 \times 0$ & $\begin{array}{c}\text { No. } \\
\text { eggs } \pm \text { SE }\end{array}$ & $\begin{array}{l}\text { No. adults } \\
\text { checked } \pm \text { SE }\end{array}$ & $\begin{array}{c}\text { Sex ratio } \\
{[q /(q+\overbrace{}^{\star})] \pm \mathrm{SE}}\end{array}$ & $9 \times \hat{0}$ & $\begin{array}{c}\text { No. } \\
\text { eggs } \pm \text { SE }\end{array}$ & $\begin{array}{l}\text { No. adults } \\
\text { checked } \pm \text { SE }\end{array}$ & $\begin{array}{c}\text { Sex ratio } \\
{[q /(q+\overbrace{}^{\star})] \pm \mathrm{SE}}\end{array}$ \\
\hline $\mathrm{Tk} \times \mathrm{Tp}$ & $32.0 \pm 0.5$ & $30.0 \pm 0.7$ & $0.185 \pm 0.435$ & $\mathrm{Tp} \times \mathrm{Tk}$ & $33.0 \pm 2.7$ & $30.3 \pm 2.2$ & 0 \\
\hline $\mathrm{I} 1 \times \mathrm{Tk}$ & $81.3 \pm 2.0$ & $78.0 \pm 1.8$ & 0 & $\mathrm{I} 1 \times \mathrm{Tp}$ & $87.5 \pm 1.7$ & $85.5 \pm 1.8$ & $0.787 \pm 0.079$ \\
\hline $\mathrm{Tk} \times \mathrm{I} 1$ & $42.8 \pm 0.3$ & $38.5 \pm 0.5$ & $0.654 \pm 0.096$ & $\mathrm{Tp} \times \mathrm{I} 1$ & $45.0 \pm 3.5$ & $42.8 \pm 3.5$ & $0.818 \pm 0.043$ \\
\hline $\mathrm{S} 1 \times \mathrm{Tk}$ & $47.3 \pm 0.6$ & $39.8 \pm 0.8$ & $0.493 \pm 0.204$ & $\mathrm{~S} 1 \times \mathrm{Tp}$ & $49.5 \pm 1.1$ & $44.3 \pm 1.4$ & $0.170 \pm 0.433$ \\
\hline $\mathrm{Tk} \times \mathrm{S} 1$ & $53.8 \pm 0.6$ & $51.8 \pm 0.5$ & $0.756 \pm 0.098$ & $\mathrm{Tp} \times \mathrm{S} 1$ & $52.3 \pm 1.3$ & $44.0 \pm 1.7$ & 0 \\
\hline $\mathrm{N} 1 \times \mathrm{Tk}$ & $41.8 \pm 2.3$ & $40.3 \pm 2.6$ & $0.796 \pm 0.079$ & $\mathrm{~N} 1 \times \mathrm{Tp}$ & $24.5 \pm 2.4$ & $20.0 \pm 1.8$ & $0.478 \pm 0.617$ \\
\hline $\mathrm{Tk} \times \mathrm{N} 1$ & $59.8 \pm 1.3$ & $58.8 \pm 1.3$ & $0.672 \pm 0.060$ & $\mathrm{Tp} \times \mathrm{N} 1$ & $18.5 \pm 1.1$ & $16.3 \pm 1.0$ & 0 \\
\hline $\mathrm{N} 2 \times \mathrm{Tk}$ & $52.8 \pm 2.5$ & $50.5 \pm 2.4$ & $0.714 \pm 0.152$ & $\mathrm{~N} 2 \times \mathrm{Tp}$ & $39.8 \pm 0.8$ & $34.5 \pm 0.9$ & $0.449 \pm 0.068$ \\
\hline $\mathrm{Tk} \times \mathrm{N} 2$ & $49.3 \pm 1.2$ & $46.3 \pm 0.8$ & $0.710 \pm 0.108$ & $\mathrm{Tp} \times \mathrm{N} 2$ & $34.3 \pm 1.0$ & $33.0 \pm 0.9$ & 0 \\
\hline $\mathrm{N} 3 \times \mathrm{Tk}$ & $52.3 \pm 1.4$ & $49.8 \pm 1.6$ & $0.837 \pm 0.045$ & $\mathrm{~N} 3 \times \mathrm{Tp}$ & $20.0 \pm 0.4$ & $17.3 \pm 0.1$ & $0.592 \pm 0.292$ \\
\hline $\mathrm{Tk} \times \mathrm{N} 3$ & $42.3 \pm 1.5$ & $28.0 \pm 1.0$ & $0.550 \pm 0.273$ & $\mathrm{Tp} \times \mathrm{N} 3$ & $52.5 \pm 2.1$ & $52.0 \pm 2.1$ & 0 \\
\hline $\mathrm{N} 5 \times \mathrm{Tk}$ & $33.5 \pm 1.9$ & $24.3 \pm 1.7$ & $0.734 \pm 0.208$ & $\mathrm{~N} 5 \times \mathrm{Tp}$ & $26.8 \pm 0.9$ & $24.0 \pm 1.2$ & $0.138 \pm 0.471$ \\
\hline $\mathrm{Tk} \times \mathrm{N} 5$ & $55.3 \pm 1.7$ & $52.3 \pm 1.6$ & $0.637 \pm 0.076$ & $\mathrm{Tp} \times \mathrm{N} 5$ & $55.0 \pm 2.2$ & $48.5 \pm 1.7$ & 0 \\
\hline $\mathrm{N} 6 \mathrm{~B} \times \mathrm{Tk}$ & $66.7 \pm 0.6$ & $62.3 \pm 1.0$ & $0.806 \pm 0.078$ & $\mathrm{~N} 6 \mathrm{~B} \times \mathrm{Tp}$ & $51.5 \pm 0.8$ & $49.8 \pm 0.4$ & $0.252 \pm 0.333$ \\
\hline $\mathrm{Tk} \times \mathrm{N} 6 \mathrm{~B}$ & $81.0 \pm 0.8$ & $63.5 \pm 0.8$ & $0.701 \pm 0.329$ & $\mathrm{Tp} \times \mathrm{N} 6 \mathrm{~B}$ & $51.5 \pm 1.3$ & $48.3 \pm 1.1$ & 0 \\
\hline $\mathrm{W} 5 \times \mathrm{Tk}$ & $20.3 \pm 1.0$ & $18.0 \pm 0.7$ & $0.946 \pm 0.205$ & $\mathrm{~W} 5 \times \mathrm{Tp}$ & $16.3 \pm 1.4$ & $15.0 \pm 1.2$ & $0.296 \pm 0.763$ \\
\hline $\mathrm{Tk} \times \mathrm{W} 5$ & $66.0 \pm 2.0$ & $59.3 \pm 1.4$ & $0.772 \pm 0.084$ & $\mathrm{Tp} \times \mathrm{W} 5$ & $54.5 \pm 1.8$ & $48.8 \pm 1.8$ & 0 \\
\hline $\mathrm{Y} 1 \times \mathrm{Tk}$ & $30.5 \pm 3.2$ & $27.3 \pm 2.9$ & $0.804 \pm 0.156$ & $\mathrm{Y} 1 \times \mathrm{Tp}$ & $34.7 \pm 2.5$ & $34.0 \pm 1.9$ & $0.292 \pm 0.103$ \\
\hline $\mathrm{Tk} \times \mathrm{Y} 1$ & $48.5 \pm 1.6$ & $46.8 \pm 1.6$ & $0.520 \pm 0.191$ & $\mathrm{Tp} \times \mathrm{Y} 1$ & $49.5 \pm 2.0$ & $39.5 \pm 1.7$ & $0.080 \pm 0.165$ \\
\hline
\end{tabular}

female offspring were produced in the cross of I1 female $\times$ Tk male. Sex ratios of offspring were high in the reciprocal cross between I1 and Tp. On the other hand, the sex ratios of Tp females mated with males of the other local populations were very low (Tp $\times$ Y 1: 0.080$)$ or zero. In the crosses between females of local populations and Tp males, the sex ratios were $0.138-0.592$.

According to Gomi and Gotoh (1996), T. kanzawai females mated with $T$. parakanzawai males produced female offspring, while few females were produced by $T$. parakanzawai females mated with T. kanzawai males. We confirmed the unidirectional fertilization of reciprocal crosses between the two species in the crosses between the standard strains Tk and Tp. The results of crossing experiments between the standard strains and the local populations showed that I1 was T. parakanzawai and the others were T. kanzawai.

\section{Sequence and recognition sites for restriction enzymes}

The lengths of ITS regions were as follows: $T$. kanzawai, 1,203 bp; T. urticae, 1,205 bp; T. pueraricola, 1,208 bp; and T. ludeni, 1,197 bp, including the PCR primers. The nucleotide sequences are available from the DDBJ/EMBL/GenBank database with accession numbers of AB076369-72. At least one recognition site for 34 to 36 of 131 restriction endonucleases was found on each sequence. Differences in the position or number of recognition sites among species were found in 22 of the enzymes. Even if there is recognition site difference between species, it is not useful for 


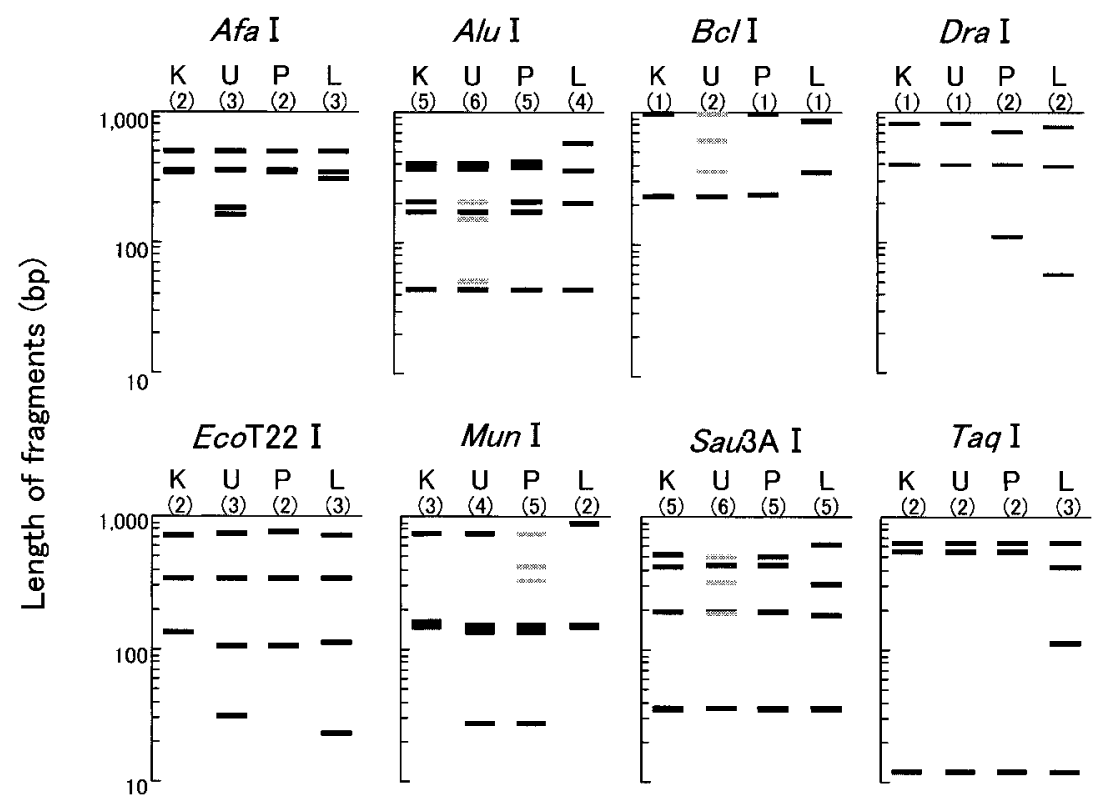

Fig. 1. RFLP banding patterns of the ITS region of rDNA expected from the sequence in each species. K: T. kanzawai, U: T. urticae, P: T. pueraricola, L: T. ludeni. Figures in parentheses show the number of recognition sites.

species discrimination if the size difference between the fragments after digestion is not big enough to be shown by electrophoresis.

The banding patterns of the fragments that would be detected by electrophoresis were expected by the fragment sizes calculated from the sequencing data and the recognition sites. Eight of the expected banding patterns are shown in Fig. 1. Many banding patterns show differences among species. However, some of the characteristic banding patterns, for example, those in T. urticae after digestion by AluI, BclI, and Sau3AI and in T. pueraricola by MunI, depend on point mutations among copies of ribosomal DNA at the recognition sites. Such point mutations cause partial digestion, increase the number of electrophoretically detectable bands, and sometimes produce characteristic banding patterns. However, partial digestion makes the fragment signal weaker and throws the judgement of the banding pattern into confusion. Additionally, very small fragments can not be detected by the agarose gel electrophoresis. Consequently, we chose two restriction endonucleases, DraI and $A f a \mathrm{I}$, as candidates for diagnostic agents.

\section{PCR-RFLP using diagnostic restriction endonu- cleases}

The expected patterns shown in Fig. 1 matched the actual banding patterns after the digestion of

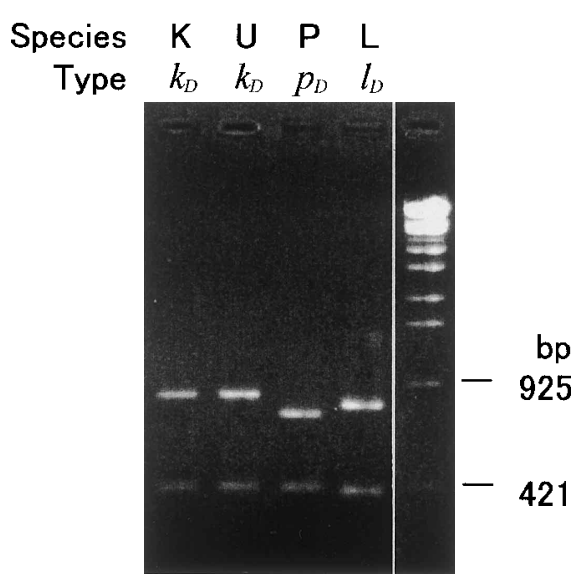

Fig. 2. Photograph of DraI-digested patterns of the PCRamplified ITS region of rDNA from a single adult female on a 3.5\% agarose gel. K: T. kanzawai, U: T. urticae, P: T. pueraricola, L: T. ludeni. The right lane shows the banding pattern of a standard size marker $(\lambda-E c o T 14 \mathrm{I})$.

amplified ITS fragments by DraI and $A f a$ I (Figs. 2 and 3). The smallest band produced by DraI in both $T$. pueraricola and T. ludeni was not detectable by electrophoresis. The sizes of the larger of the two detected fragments followed the order $T$. kanzawai $=T$. urticae $>T$. ludeni $>T$. pueraricola, characterizing the latter two species. The fragments produced by $A f a \mathrm{I}$ characterized $T$. urticae with a smaller band, which was expected to consist of 163 and $185 \mathrm{bp}$ fragments (Fig. 1). The bands appear- 
ing around $350 \mathrm{bp}$ were also estimated to be complex, with two similar-sized fragments except in $T$. urticae (Fig. 1). Consequently, the banding patterns produced by DraI were grouped into three types,

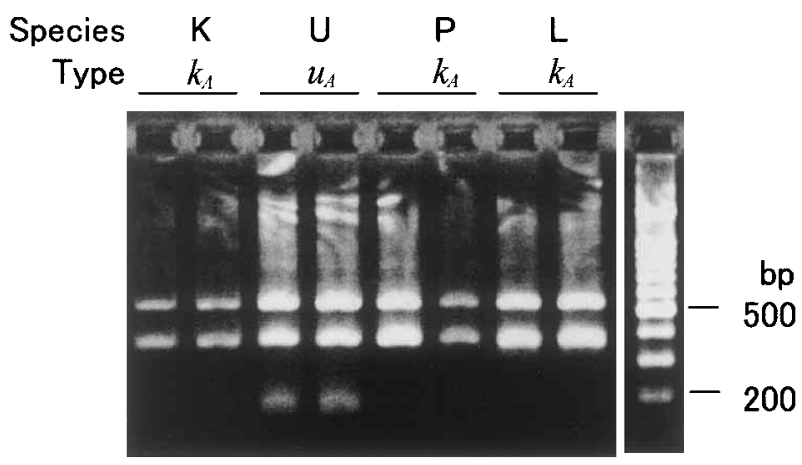

Fig. 3. Photograph of AfaI-digested patterns of the PCRamplified ITS region of rDNA from a single adult female on a 3.5\% agarose gel. K: T. kanzawai, U: T. urticae, P: T. pueraricola, L: T. ludeni. The right lane shows the banding pattern of a standard size marker (100 bp ladder).
$k_{D}, p_{D}$, and $l_{D}$, and those by $A f a \mathrm{I}$ into two types, $k_{A}$ and $u_{A}$, on the basis of perceptible variation. This set of RFLP banding patterns should allow the Tetranychus species to be discriminated: $k_{D}$ and $k_{A}$ banding patterns indicate T. kanzawai, $k_{D}$ and $u_{A}$ indicate T. urticae, $p_{D}$ and $k_{A}$ indicate T. pueraricola, and $l_{D}$ and $k_{A}$ indicate T. ludeni.

The types of PCR-RFLP banding patterns detected in the local populations and laboratory strains are shown in Table 3, except for that of I1, which we identified as T. parakanzawai. We found no contradiction between the morphological and genetic criteria in any population. This result strongly supports the usefulness of PCR-RFLP for the discrimination of adult females of the four Tetranychus species. After some modification, this genetic criterion could be applied to any immature stages.

On the other hand, the Tp strain showed the same banding patterns as T. kanzawai: $k_{D}$ and $k_{A}$

Table 3. Types of fragments digested by restriction endonucleases

\begin{tabular}{|c|c|c|c|c|c|}
\hline \multirow{2}{*}{ Species } & \multirow{2}{*}{ Population } & \multicolumn{2}{|c|}{ DraI } & \multicolumn{2}{|c|}{$A f a \mathrm{I}$} \\
\hline & & No. $q 9$ tested & Type of fragment ${ }^{\mathrm{a}}$ & No. $q 9$ tested & Type of fragment ${ }^{\mathrm{b}}$ \\
\hline \multirow[t]{8}{*}{ T. kanzawai } & S1 & 7 & $k_{D}$ & 8 & $k_{A}$ \\
\hline & N1 & 4 & $k_{D}$ & 2 & $k_{A}$ \\
\hline & N2 & 2 & $k_{D}$ & 2 & $k_{A}$ \\
\hline & N3 & 1 & $k_{D}$ & 1 & $k_{A}^{A}$ \\
\hline & N5 & 2 & $k_{D}$ & 2 & $k_{A}$ \\
\hline & N6B & 3 & $k_{D}$ & 3 & $k_{A}$ \\
\hline & W5 & 2 & $k_{D}$ & 2 & $k_{A}$ \\
\hline & Y1 & 2 & $k_{D}$ & 2 & $k_{A}$ \\
\hline \multirow[t]{5}{*}{ T. urticae red form } & W1 & 4 & $k_{D}$ & 3 & $u_{A}$ \\
\hline & W2 & 4 & $k_{D}$ & 2 & $u_{A}$ \\
\hline & W3 & 3 & $k_{D}$ & 3 & $u_{A}$ \\
\hline & $\mathrm{C} 2$ & 2 & $k_{D}$ & 2 & $u_{A}$ \\
\hline & $\mathrm{C} 3$ & 6 & $k_{D}$ & 4 & $u_{A}$ \\
\hline \multirow[t]{3}{*}{ T. urticae green form } & $\mathrm{L}$ & 2 & $k_{D}$ & 2 & $u_{A}$ \\
\hline & N6A & 4 & $k_{D}$ & 2 & $u_{A}$ \\
\hline & $\mathrm{C} 4$ & 5 & $k_{D}$ & 5 & $u_{A}$ \\
\hline \multirow[t]{3}{*}{ T. pueraricola } & $\mathrm{I} 2$ & 7 & $p_{D}$ & 6 & $k_{A}$ \\
\hline & G1 & 2 & $p_{D}$ & 2 & $k_{A}$ \\
\hline & N7 & 3 & $p_{D}$ & 3 & $k_{A}^{A}$ \\
\hline \multirow[t]{3}{*}{ T. ludeni } & $\mathrm{C} 1$ & 7 & $l_{D}$ & 5 & $k_{A}$ \\
\hline & W4 & 5 & $l_{D}$ & 3 & $k_{A}$ \\
\hline & W9B & 2 & $l_{D}$ & 2 & $k_{A}^{A}$ \\
\hline
\end{tabular}

\footnotetext{
${ }^{a}$ See Fig. 2. ${ }^{\mathrm{b}}$ See Fig. 3.
} 


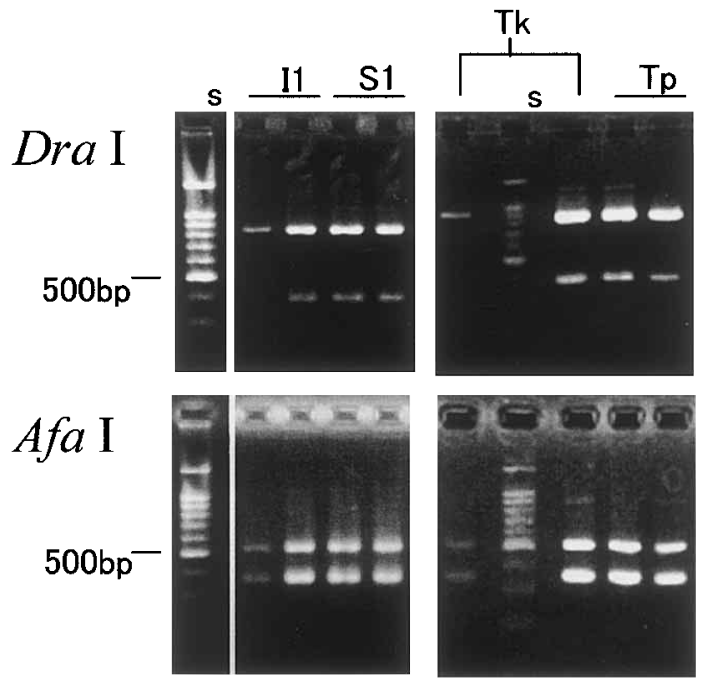

Fig. 4. Comparison of ITS fragments digested by DraI and $A f a \mathrm{I}$ between T. kanzawai ( $\mathrm{S} 1$ and $\mathrm{Tk}$ ) and T. parakanzawai (I1 and Tp). s: standard size marker (100 bp ladder).

(Fig. 4). This indicates that T. parakanzawai is not discriminated from T. kanzawai by the PCR-RFLP analysis developed in this study. The I1 population also showed the $k_{D}$ and $k_{A}$ banding patterns in RFLP (Fig. 4).

\section{DISCUSSION}

We settled the problem of how to discriminate adult females of T. kanzawai, T. urticae, T. pueraricola and T. ludeni by electrophoretic separation of banding patterns of the ribosomal ITS region. During the past decade, three new species of Tetranychus-T. pueraricola, T. parakanzawai and T. okinawanus Ehara - have been recorded (Ehara, 1995, 1999; Ehara and Gotoh, 1996). Additionally, Ehara and Yamaguchi (2001) discovered Tetranychus neocaledonicus André in Amami-Ōshima, Japan. Consequently, the number of Tetranychus species in Japan has been increased to eleven. Adult females of these species are reddish except for the green form of $T$. urticae. Recent trade globalization has improved the chance of invasion by exotic pests to new areas. Several controversies in classification-for example, T. urticae and Tetranychus cinnabarinus (Boisduval) (Dupont, 1979; Gotoh et al., 1993; Goka et al., 1996), and T. kanzawai and Tetranychus hydrangeae Pritchard and Baker (Ehara and Wongsiri, 1975; Navajas et al., 2001) are evidence of the difficulty of identifying
Tetranychus species solely by morphological characters, and of availability of molecular markers. We expect that the identification method using PCR-RFLP can be generalized to include species we have not analyzed. However, agarose gels and acrylamide gels are usually temporary, and it is difficult to exactly compare small differences between close bands on photographs of separate gels. On the other hand, sequence analysis is too expensive and too time consuming to be used in routine affairs such as quarantine.

We have developed a model of RFLP patterns based on the ITS sequence and the results of computer analysis of the recognition site for restriction endonucleases (Fig. 1). All expected banding patterns were represented by electrophoresis. Such standardized molecular data will be convenient for quarantine services, because it is easy to compare foreign species with domestic ones without importing species. If the primer set used in this study can be used for every species, then we can create a worldwide catalogue of ITS RFLPs for Tetranychus.

\section{ACKNOWLEDGEMENTS}

We thank Professor T. Gotoh, Ibaraki University, for providing the standard strains and other laboratory strains of spider mites and for valuable suggestions; and Mr. N. Hinomoto, National Institute of Agrobiological Sciences, for providing the primer sequences and a laboratory strain of spider mite. We also thank Dr. M. Inoue, Dr. Y. Kunimoto, Dr. M. Morishita, Dr. A. Kawai, Mr. N. Fukuda, Mr. Y. Yoshida, Mr. S. Toda and Mr. Y. Takagi for their help in collecting spider mites.

\section{REFERENCES}

Dupont, L. (1979) On gene flow between Tetranychus urticae Koch, 1836 and Tetranychus cinnabarinus (Boisduval) Boudreaux, 1956 (Acari: Tetranychidae): synonymy between the two species. Entomol. Exp. Appl. 25: 297-303.

Ehara, S. (1995) A new species of Tetranychus (Acari, Tetranychidae) from the Ryukyu Islands. Jpn. J. Entomol. 63: 229-233.

Ehara, S. (1996) Taxonomy. In Principles of Plant Acarology (S. Ehara and N. Shinkaji eds.). Zenkoku-nōson-kyōikukyōkai, Tokyo, pp. 39-81 (in Japanese).

Ehara, S. (1999) Revision of the spider mite family Tetranychidae of Japan (Acari, Prostigmata). Species Diversity 4: 63-141.

Ehara, S. and T. Gotoh (1996) Two new species of spider mites occurring in Japan (Acari, Tetranychidae). J. Acarol. Sci. Jpn. 5: 17-25.

Ehara, S. and M. Masaki (1989) Notes on two Japanese species of Tetranychus (Acarina: Tetranychidae). Acta 
Arachnol. 38: 49-54.

Ehara, S. and T. Wongsiri (1975) The spider mites of Thailand (Acarina: Tetranychidae). Mushi 48: 149-185.

Ehara, S. and T. Yamaguchi (2001) Discovery of Tetranychus neocaledonicus Andre (Acari, Tetranychidae) from Amami-Oshima Island, Japan. Plant Protection 55: 268-272 (in Japanese).

Enohara, K. and H. Amano (1996) Simple method for discriminating six common species of red Tetranychus spider mites (Acari: Tetranychidae) in Japan. Jpn. J. Appl. Entomol. Zool. 40: 311-315.

Gasparich, G. E., W. S. Sheppard, H.-Y. Han, B. A. McPheron and G. J. Steck (1995) Analysis of mitochondrial DNA and development of PCR-based diagnostic molecular markers for Mediterranean fruit fly (Ceratitis capitata) populations. Insect Mol. Biol. 4: 61-67.

Goka, K., K. Okabe, M. Yoneda and S. Niwa (2001) Bumblebee commercialization will cause worldwide migration of parasitic mites. Mol. Ecol. 10: 2095-2099.

Goka, K. and A. Takafuji (1997) Identification among seven species of spider mites (Tetranychus) (Acari: Tetranychidae) based on enzyme differentiation detected by electrophoresis. Appl. Entomol. Zool. 32: 127-134.

Goka, K., A. Takafuji, S. Toda, T. Hamamura, Mh. Osakabe and S. Komazaki (1996) Genetic distictness between two forms of Tetranychus urticae Koch (Acari: Tetranychidae) detected by electrophoresis. Exp. Appl. Acarol. 20: 683-693.

Gomi, K. and T. Gotoh (1996) Host plant preference and genetic compatibility of the Kanzawa spider mite, Tetranychus kanzawai Kishida (Acari: Tetranychidae). Appl. Entomol. Zool. 31: 417-425.

Gotoh, T., J. Bruin, M. W. Sabelis and S. B. J. Menken (1993) Host race formation in Tetranychus urticae: genetic differentiation, host plant preference, and mate choice in a tomato and a cucumber strain. Entomol. Exp. Appl. 68: 171-178.

Gotoh, T., J. Gutierrez and M. Navajas (1998) Molecular comparison of the sibling species Tetranychus pueraricola Ehara et Gotoh and T. urticae Koch (Acari: Tetranychidae). Entomol. Sci. 1: 55-57.

Helle, W. and L. P. Pijnacker (1985) Parthenogenesis, chromosomes and sex. In Spider Mites. Their Biology, Natural Enemies and Control, Vol. 1A (W. Helle and M. W. Sabelis eds.). Elsevier, Amsterdam, pp. 129-139.

Hinomoto, N. and A. Takafuji (2001) Genetic diversity and phylogeny in the Kanzawa spider mite, Tetranychus kan- zawai, in Japan. Exp. Appl. Acarol. 25: 355-370.

Mullin, C. A. and B. A. Croft (1983) Host-related alterations of detoxification enzymes in Tetranychus urticae (Acari: Tetranychidae). Environ. Entomol. 12: 1278-1282.

Nasmith, C. G., D. Speranzini, R. Jeng and M. Hubbes (1996) RFLP analysis of PCR amplified ITS and 26S ribosomal RNA genes of selected entomopathogenic nematodes (Steinernematidae, Heterorhabditidae). J. Nematol. 28: $15-25$.

Navajas, M. and B. Fenton (2000) The application of molecular markers in the study of diversity in acarology: a review. Exp. Appl. Acarol. 24: 751-774.

Navajas, M., J. Gutierrez, O. Bonato, H. R. Bolland and S. Mapangou-Divassa (1994) Intraspecific diversity of cassava green mite Mononychellus progresivus (Acari: Tetranychidae) using comparisons of mitochondrial and nuclear ribosomal DNA sequences and cross-breeding. Exp. Appl. Acarol. 18: 351-360.

Navajas, M., J. Gutierrez and T. Gotoh (1997) Convergence of molecular and morphological data reveals phylogenetic information on Tetranychus species and allows the restoration of the genus Amphitetranychus (Acari: Tetranychidae). Bull. Entomol. Res. 87: 283-288.

Navajas, M., J. Gutierrez, M. Williams and T. Gotoh (2001) Synonymy between two spider mite species, Tetranychus kanzawai and T. hydrangeae (Acari: Tetranychidae), shown by ribosomal ITS2 sequences and cross-breeding experiments. Bull. Entomol. Res. 91: 117-123.

Orui, Y. (1996) Discrimination of the main Pratylenchus species (Nematoda: Pratylenchidae) in Japan by PCRRFLP analysis. Appl. Entomol. Zool. 31: 505-514.

Orui, Y. and T. Mizukubo (1999) Discrimination of seven Pratylenchus species (Nematoda: Pratylenchidae) in Japan by PCR-RFLP analysis. Appl. Entomol. Zool. 34: 205-211.

Osakabe, Mh. (1984) Esterase zymogram of the citrus red mite, Panonychus citri (McGregor), on citrus and pear. Jpn. J. Appl. Entomol. Zool. 28: 1-4 (in Japanese with English summary).

Osakabe, Mh. (1987) Esterase activities and developmental success of the citrus red mite, Panonychus citri (McGregor) (Acarina: Tetranychidae), on several plants. Appl. Entomol. Zool. 22: 35-44.

Sula, J. and F. Weyda (1983) Esterase polymorphism in several populations of the two-spotted spider mite, Tetranychus urticae Koch. Experientia 39: 78-79. 